\title{
Trustee reputation in securitization: When does it matter?
}

\author{
Solomon Y. Deku* \\ Nottingham Trent University, Nottingham Business School, \\ Nottingham, United Kingdom \\ Alper Kara \\ University of Huddersfield, Huddersfield Business School \\ Huddersfield, United Kingdom \\ David Marques-Ibanez \\ European Central Bank, Financial Research Division, \\ Frankfurt, Germany
}

\begin{abstract}
We consider the role of trustees -who are nominated to protect the interests of investors- in securitization pricing and whether investors rely on them to mitigate risks. In particular, we examine the effect of trustee reputation on initial yield spreads of European mortgage-backed security (MBS) issuances between 1999 and the first half of 2007. We find that engaging reputable trustees led to lower spreads during the credit boom period prior to the 2007-2009 financial crisis. Our findings suggest that trustees' reputation was considered by investors to be more important when risk assessment became more challenging.
\end{abstract}

Keywords: Securitization; MBS; trustee reputation; 2007-2009 financial crisis

JEL classification: G21; G28

\footnotetext{
* Corresponding author: Solomon Y Deku (solomon.deku@ntu.ac.uk), Alper Kara (a.kara@hud.ac.uk), David Marques-Ibanez (david.marques@ecb.int). The authors thank, in particular, Alistair Milne, Philip Molyneux, Yener Altunbas, Alberto Pozzolo, Noel O'Sullivan and Mark Rhodes for helpful comments and discussions. Our thanks also to participants at Portsmouth-Fordham 2016 "Banking and Finance" conference, the 4th European Conference on Banking and the Economy and at seminars held at the European Central Bank, Loughborough University and University of Hull. The opinions expressed in this paper are those of the authors only and do not necessarily reflect those of the ECB.
} 


\section{Introduction}

Investors in mortgage-backed securities (MBSs) suffered tremendous losses during the 2007-2009 financial crisis. Stakeholders -issuers, rating agencies, trustees, and investors- across the securitization chain were blamed for failing to meet expected standards. Issuers relaxed lending criteria for mortgages that underlay the MBSs (Keys et al., 2009; Keys et al., 2012; Jiang et al., 2013; Kara et al., 2016), rating agencies underestimated the risk embedded in these securities (Coval et al., 2009; Brennan et al., 2009; Richardson and White, 2009), trustees failed to enforce repurchase clauses (Dolmetsch, 2014; Stempel, 2016; Yoon, 2014) and investors were criticised for being overly reliant on credit ratings (Mahlmann, 2012). Modern securitization has grown significantly since the 1980s. Although the use of securitization techniques was initially a United States (US) phenomenon, the swift growth of European securitization in the late 1990s has been attributed to the introduction of the Euro and increased financial market integration. Outstanding volumes climbed by about $1400 \%$ from $\$ 139$ billion in 1999 to $\$ 2$ trillion in 2007. These volumes were largely driven by the securitization of mortgages, which accounted for $62 \%$ of European securitization outstanding by mid- 2007 .

In this paper, we consider the role of trustees in securitization pricing and whether investors relied on trustees to mitigate MBS risks. Trustees play an important role on securitization transactions. They are nominated to protect the interests of investors by managing the special purpose vehicle (SPV) on their behalf. As agents, trustees protect investors' interests by ensuring compliance of issuers and servicers with the agreements governing the securitization deal (Gorton and Metrick, 2012a). They are also responsible for channelling payments to investors and notifying them of representation and warranty violations. This data intensive role also involves validating the performance of the collateral underlying the MBS on behalf of investors (Cetorelli and Peristiani, 2012). Investors rely on trustees to enforce repurchase obligations as provisions in the indenture do not allow direct repurchase requests from investors.

We examine whether investors price the efficacy of the trustee mechanism into initial MBS prices. In particular, given the certification value of reputation in the financial services industry (Booth and Smith, 1986; Titman and Trueman, 1986; Fang, 2005), we hypothesise that investors may have attempted to mitigate risks by considering trustee reputation when pricing MBS. We test our arguments by examining the initial yields of MBS issuances. A number of studies show that investors incorporate the potential costs of misaligned interests in the primary yields of MBSs by accounting for issuer size, rating bias, collateral, and tranche structure (Fabozzi and Vink, 2012a, 2015; He et al., 
2012). We contend that larger and more active trustees may be perceived as more efficient in identifying discrepancies and notifying investors of breaches accordingly. They may create value for investors, especially during credit events. Consequently, MBSs with reputable trustees should have lower risk and lower spreads.

We contribute to the literature by factoring trustee reputation into the determination of primary spreads to examine whether investors incorporate potential trustee indiscipline in initial valuations of MBSs. This is a dimension of securitization pricing that has not been investigated. For example, Andres et al. (2012) study the influence of trustees in pricing but only for high yield US corporate bonds. It is conceivable that investors relied on trustees to detect fraud for a multiple reasons (Colloff, 2005). First, except for the servicer, the trustee remains the main party with direct administrative responsibilities from deal closure to the maturity of the MBSs. Second, the trustee performs a fiduciary role in an event of default. Third, trustees tend be experts in regulatory and compliance issues. In addition, they tend to have marked international presence to tackle collateral liquidation and litigation in various jurisdictions. Finally, trustees typically offer enhanced services in excess of conventional trustee services for additional fees.

We build a unique dataset comprising 4,201 tranches from 730 transactions originated in Europe between 1999 and the first half of 2007. Our focus is on the European market whose growth was mainly due to private market forces rather than government-sponsored enterprises (GSEs) in the US market. The US securitization markets expanded primarily due to the influence of the GSEs. However, EU law (Articles 87 and 88 of the EC treaty) prohibits state aid in the form of guarantees as this may distort competition in the mortgage markets (Coles and Hardt, 2000). Furthermore, the growth of European securitization was largely inhibited by regulatory constraints (Stone and Zissu, 2000). ${ }^{1}$

The outstanding growth of the European mortgage securitization markets has been attributed to increased institutional demand, technological and financial innovation, and the introduction of the Euro (Altunbas et al., 2009). The adoption of the Euro resulted in the elimination of exchange rate risk in the Euro area, lowered transaction costs, and increased liquidity. However, the growth of the securitization markets has been heterogeneous across the Euromarket. ${ }^{2}$ This growth was attained with

\footnotetext{
${ }^{1}$ Most of continental Europe required specific regulation to allow the issuance of MBSs (Stone and Zissu, 2000). This setback was addressed by the enactment of securitization-enabling regulation in Belgium, France, Germany, Greece, Italy, Portugal and Spain.

${ }^{2}$ Asset securitization in the Euro area is driven by countries that experienced real estate repricing after the introduction of the Euro in Italy, Spain, Netherlands and Portugal (Altunbas et al., 2009).
} 
certain associated costs: agency problems that misaligned incentives, increased complexity and opaqueness of securitized bonds that rendered efficient pricing difficult (Segoviano et al., 2015). Given this backdrop, investors in Europe may have relied on other avenues such as credit ratings and trustees for mitigating MBS risks. Therefore, we aim to assess whether investors may have incorporated the experience and reputation of trustees in the pricing of MBSs.

We find that engaging reputable trustees led to lower MBS spreads during the credit boom period (between 2005 and the first half of 2007) prior to the 2007-2009 financial crisis. Furthermore, the importance of reputable trustees for risk mitigation increased gradually each year between 2005 and 2007 as the crisis loomed. Our findings suggest that the reputation of trustees was deemed to be a critical yardstick as risk assessment became more difficult.

The paper is structured as follows. Section 2 provides a background to the securitization trustee's role and reviews the extant literature. Section 3 describes the data and methodology used. Section 4 presents the results and Section 5 puts forward the conclusions.

\section{Literature Review}

Our paper is related to three strands of the literature, which we review in the sub-sections below. Firstly, we explain the role of securitization trustees and the problems these intermediaries face. Subsequently, we review studies on the role of intermediaries as delegated monitors in the securitization context. Finally, the third strand of the literature examines the certification role of intermediary reputation in financial markets.

\subsection{The Role of the Securitization Trustee}

Securitization involves the conversion of relatively illiquid assets such as mortgages into tradable securities. This is achieved by transferring a pool of mortgage loans to a Special Purpose Vehicle (SPV), established solely for this transaction. With guidance from ratings agencies, an underwriter structures the asset pool into tranches, which are then rated and issued as MBSs to investors. The key aspects of the securitization transaction are governed by a contractual document known as a pooling and servicing agreement (PSA).

The PSA governs the transfer of mortgage loans to the SPV, management of the SPV, servicing of the pooled mortgages and issuance of the MBSs to investors. The foremost section of this contract defines the rights and obligations of the deal parties (originators, servicers, trustees and investors). The 
subsequent sections focus on structural considerations, servicing standards, and the reporting framework (McQueen et al., 2013).

The originator (also termed the seller, issuer, or sponsor) advances mortgages to borrowers and aggregates these mortgages into an asset pool while the servicer collects periodic payments from borrowers. Consequently, the originator and servicer ${ }^{3}$ are more knowledgeable about the mortgages securitized than other deal parties, particularly investors. The originator usually retains an obligation to augment or substitute assets within the pool if asset values fall below certain thresholds. In this regard, the trustee is empowered to demand the addition of new assets or replacement of assets that no longer conform to asset requirements specified in the PSA (ABA, 2010). The servicer is also responsible for reporting collections and loss amounts to trustees who are in turn charged with the calculation and distribution of cash flows/losses based on the servicer's reports. Furthermore, trustees are required to review servicer reports to detect breaches of warranty and representations by the issuer and servicer.

Morton (2005) explains that the pre-default duties of trustees in securitization arrangements are conventionally twofold. Firstly, the trustee provides non-discretionary agency services that are largely ministerial in nature such as acting as analytics provider, account custodian (or cash manager) and principal paying agent. ${ }^{4}$ Secondly, as the asset custodian, the trustee is the legal representative of noteholders and holds legal title to the SPV's assets on their behalf. As a delegated monitor, the trustee holds lien on the assets and is authorised to enforce specified remedies in the interest of investors as dictated by the transaction documentation or a controlling majority of noteholders. A banking institution usually performs the former role while the latter must be performed by a trust company. However, most trustees package all these services such that they become a one-stop shop for all trust and administrative services.

In an event of default ${ }^{5}$, the trustee's responsibilities surpass detecting negligence and the trustee is now required to conduct the affairs of the SPV according to the prudent man rule ${ }^{6}$. The trustee is

\footnotetext{
${ }^{3}$ In practice, the originator and servicer are commonly the same institution or of the same banking group (He et al., 2012).

${ }^{4}$ The analytics provider is responsible for preparing regular (usually monthly) reports on the notes, deal performance and the evolution of the portfolio composition. The account custodian is tasked with operating and monitoring the SPV's bank account and the paying agent. Collections from the servicer are passed on to the paying agent who uses these funds to settle transaction participants' fees and expenses, interest and principal payments on the obligations due on the tranches according to the priority of payments (waterfall provisions) in the transaction documentations (Slaughter and May, 2010; ABA, 2010)

${ }^{5}$ Concerns regarding defaults also arise where the servicer fails to make scheduled remittances/advances to the trust or where the originator/servicer violates any covenants as indicated in the PSA. Where a breach occurs, the trustee transforms into an active participant and proactively notifies investors of the said breach and awaits the instructions of the next course of action on investors' behalf.

${ }^{6}$ In Speight v Gaunt [1883] UKHL 1, Lord Blackburn is quoted saying “... as a general rule a trustee sufficiently discharges his duty if he takes in managing trust affairs all those precautions, which an ordinary prudent man of business would take in managing similar affairs of his own". Furthermore, quoting Lord Lindley in the case of In Re Whiteley [1886] 33 Ch. Div. 347 “....the duty of a trustee is not to take such care only as a prudent man would
} 
required to enforce remedies when certain trigger events occur (such as a covenant breaches). The trustee either relies on its own discretion or the instruction of a controlling majority of the investors to enforce the obligations of the issuer/servicer (Macaulay, 2004). In such cases, the trustee is expected to leverage its bargaining power to protect the interest of noteholders: for instance, by securing an active seat on creditor committees, and making timely information requests from the issuer to inform the decision to switch from a passive to an active stance. An experienced trustee knows the optimal moment to call for dialogue amongst bondholders and issuers, and when to seek legal/financial advice (Wilmington Trust, 2017). Experienced trustees coordinate the envisioned actions of noteholders and avoid the problems and costs associated with the actions of individual investors. Trustees stand out based on factors including staffing levels, locations, information systems and experience in problem solving (Coleman and Libunao, 2013).

Prior to default, the trustee's role is limited to channelling funds to investors and providing performance reports based on data supplied by the servicer. The trustee examines the servicer reports to determine whether the SPV is liquid enough to meet monthly principal and interest disbursement obligations to investors. This is largely acquiescent, as their duty at this stage does not include actively monitoring the originator/servicer. The PSA often specifies representations and warranties in relation to mortgage origination and underwriting standards. If any of these are breached, the sole remedy stipulated in the PSA is usually the repurchase of the defective mortgages. Trustees are responsible for determining whether mortgage loan losses are a consequence of the breach of particular representations or warranties (Buckley, 2010). It has been suggested that some trustees failed to verify the accuracy of data supplied by servicers as they lacked the ability to do so. Thus, some trustees tend to enforce representations and warranties based on the honour system even though they have litigation as a disciplining device at their disposal (Levitin, 2010).

Although the precise role of trustees is specified in the PSA, market participants including investors and rating agencies have increasingly assumed that trustees have a comprehensive active monitoring role. However, some of these PSAs are lengthy contractual documents which tend to be vague and ambiguous. Consequently, investors unrealistically expect trustees to perform the duties of other parties such as servicers (ABA, 2010).

take if he had only himself to consider, the duty rather is to take such care as an ordinary prudent man would take if he were minded to make an investment for the benefit of other people for whom he felt morally bound to provide." 
Moreover, Morton (2005) argues that trustees' compensation does not cover services they have not been commissioned for. Thus, they are not appropriately compensated for active monitoring. In addition, trustees have no commercial interest in the securitization transaction and they merely follow documentation to determine the appropriate course of action in given circumstances. Trustees perform a range of ministerial duties and take enforcement actions on behalf of investors, if breaches are discovered. In his congressional witness statement, Levitin (2010) states that, the trustee's duties are largely limited unless a default event occurs. ${ }^{7}$ Although the role of the trustee is mostly passive, this function becomes active when the deal or the issuer is experiencing distress or default. The duties of the trustee during such circumstances are variable and relatively fluid (Schwarcs and Sergi, 2008).

One strand of literature focuses on the problems trustees encounter. Allon (2009) argues that trustees experience significant difficulty in keeping up with technological advancements and the increasing complexity of assets in their custody. As transactions become more complex, the trustee's role of monitoring payments and other parties grows complicated (Spiotto, 2012). Furthermore, relative to other parties, trustees' fees are the lowest hence their compensation may not reflect the increasing complexity of structured instruments. Additionally, they may have been under-resourced or lacked the incentive to detect fraud and misrepresentation in structured transactions (Colloff, 2005; Allon, 2009). Despite all these barriers, we expect that reputable trustees are better situated to counter these drawbacks, or are at least perceived to be so.

\subsection{Intermediaries as delegated monitors}

Traditional financial intermediation theories focus on the ability of intermediaries to reduce the frictions of transaction costs and asymmetric information (Allen and Santomero, 1997). The securitization chain is fraught with several degrees of information asymmetries where one party usually has an information advantage over another regarding the quality of the underlying assets (Ashcraft and Schuermann, 2008). For instance, originators/servicers are more knowledgeable than investors are about collateral quality. Adverse selection occurs where lenders securitize low quality loans and the ex-post moral hazard problems emerge because of reduced incentives to monitor underlying borrowers after the transaction closes. With regard to servicing, the main areas of contention are reimbursable costs, mortgage modification and foreclosure decisions. ${ }^{8}$ Investors could

\footnotetext{
${ }^{7}$ In most cases, default events depend on the financial condition of the originator/servicer.

${ }^{8}$ First, for mortgages that are less than 90 days delinquent, the servicer must advance interest payments to the trust. Second, in the event of foreclosure, the servicer incurs all expenses out of pocket. The servicer is only reimbursed when the property is sold, consequently, this creates an incentive for the servicer to overstate expenses particularly during periods of high recovery rates. Finally, since the servicer's compensation is a fixed percentage of mortgages outstanding, there is an incentive to modify terms and defer foreclosure on delinquent mortgages.
} 
address this by stipulating stringent modification and foreclosure rules in the PSA or by granting the servicer autonomy to administer the servicing function in the best interests of investors. In the absence of a trustee, these options would require investors to actively monitor the servicer's expenses.

The securitization arrangement presents collective action and free-rider (under-monitoring) problems as the tranched notes are issued to multiple investors. ${ }^{9}$ On the one hand, ownership fluidity, fragmented ownership, investor anonymity and bond liquidity worsen the collective action problem by essentially limiting concerted investor effort (Schwarcs and Sergi, 2008). On the other hand, no single investor has the incentive to incur the fixed cost of monitoring the borrower and enforcing covenants. The traditional financial intermediation literature suggests engaging a delegated monitor to mitigate both problems where an intermediary - the trustee - monitors the borrower(s) on behalf of the dispersed lenders (Diamond, 1984; Haubrich, 1989; Diamond, 1996). Thus, the financial intermediary minimises monitoring costs by avoiding the duplication of efforts in information production. Berlin and Loeys (1988) argue that although engaging a delegated monitor is more efficient, incentivising the intermediary can be costly. Therefore, there is a trade-off between the inefficiencies of inflexible bond covenants and the agency costs arising from hiring an intermediary. Furthermore, the legal literature (Schwarcs and Sergi, 2008; Bazzana, 2012) agrees that the appointment of a trustee is a more efficient option because this intermediary could facilitate coordination of strategies among investors and mitigate costly individual investor actions.

The free rider problem is resolved if the issuer, rather than investors, compensates the trustee (Smith and Warner, 1979). This setup creates an incentive for the issuer to persuade the trustee to disregard contraventions of the covenants stipulated in the PSA. However, bribing a reputable trustee can be quite costly as large trustees thrive on the value of their reputation. Therefore, being implicated in a bribery scandal could severely damage their appeal to investors and issuers alike. Consequently, issuers would prefer reputable trustees to engender positive market perception and minimise borrowing costs. Investors would also prefer honest trustees as trustee credibility is expected to mitigate adverse issuer behaviour post issuance.

\footnotetext{
${ }^{9}$ Securitization involves aggregating and conveying relatively homogenous assets from an originator to a bankruptcy remote SPV. Assets are tranched to accommodate different risk and return profiles of various investors [see for example, Ashcraft and Schuermann (2008) for a comprehensive review of the frictions within the securitization process]. This pooling and tranching mechanism deviates from the traditional intermediation model. However, banks remain the key driving force of the proliferation of mortgage-backed securitization. They tend to play critical roles throughout the life of an MBS as issuer (originator), servicer or underwriter (Cetorelli and Peristiani, 2012). Generally, the issuer engages an underwriter to analyse investor demand and structure, price, and market the issue (Choudhry, 2013). The underwriter structures the notes in consultation with the rating agencies to meet the riskreturn profiles of potential investors.
} 


\subsection{Reputation Signalling}

Our research is related to the literature on the certification role of intermediary reputation. In the model of Chemmanur and Fulghieri (1994), investment banks acquire reputation by maintaining strict evaluation standards and their credibility is dependent on past deals. They show that, in equilibrium, reputable intermediaries underwrite safer issues and secure higher prices for issuers. Booth and Smith (1986) model reputation as a bonding strategy to address information asymmetry problems between intermediaries and investors. They show that reputational capital is positively correlated with quality under information asymmetry. Using a sample of over 3000 bonds issued between 1991 and 2000, Fang (2005) finds that reputable banks that offer higher quality underwriting services are able secure lower yields and higher net proceeds for issuers.

Our paper is also closely related to the empirical work of Andres et al. (2012) on corporate bond pricing. They examine the inital yields of US non-investment-grade corporate bonds issued between 2000 and 2008, and find that engaging trustees with underwriting businesses reduced issuer borrowing costs by at least 33 basis points after conditioning on credit ratings. Consistent with superior monitoring efforts, they also find significantly lower bond defaults and less downgrade risk associated with these trustees. They interpret their results as evidence of reputational spillover effects of intermediaries that provide multiple services within a market segment. However, they do not find any evidence in support of larger trustees being better debt monitors. Based on a sample of US MBS issued between 2000 and 2006, He et al. (2012) find that launch spreads were higher for MBSs issued by reputable issuers (based on marketshare) between 2004 and 2006. They show that spreads rose because investors price the increased risk of reputable issuers securing inflated ratings especially during boom periods.

\section{Data and Methodology}

\subsection{Data Sources}

For each deal, Dealogic provides basic information on collateral types (residential and commercial mortgages), the number of tranches, composite credit rating, primary yield spread in basis points over the reference rate, asset origin, tranche and deal value. We manually collect other deal and tranche characteristics, including initial constituent credit ratings, maturity (measured by weighted average life as explained below) and the identity of deal trustees' data from Bloomberg. 


\subsection{Data Selection}

We collect data on all European MBS issuances between 1999 and the first half of 2007 from Dealogic and Bloomberg. This sample consists of deal and tranche level data on residential and commercial MBSs. The cut-off date is chosen to preclude the influence of changing attitudes towards structured finance in the latter half of 2007. We focus on MBS issuances as these form the largest component of the securitization market. At the end of the second quarter of 2007, MBSs accounted for $62 \%$ of securitized bonds outstanding (SIFMA, 2017). More specifically, residential MBS (RMBS) accounted for $50 \%$ of all issuances while commercial MBS (CMBS) constituted approximately $12 \%$ of the total securitization volume outstanding.

Tranches in our initial sample are either floating rate or fixed rate bonds issued in the Euromarket. However, we restrict our sample to floating rate tranches in order to circumvent the difficulties associated with estimating a consistent benchmark yield curve for each fixed rate tranche. For the floating rate notes, we use the quoted spreads in excess of the relevant benchmark (e.g. 3month LIBOR/3-month EURIBOR) as a measure of funding/borrowing cost, where the benchmark rate represents the rates at which highly rated banks can obtain unsecured debt. These spreads represent extra compensation for credit, liquidity and optionality risks. However, the optionality risk in the price for floating rate tranches is marginal (Fabozzi and Vink, 2015). Therefore, the initial spreads reflect the risk premiums compensating for credit risk above LIBOR/EURIBOR and the liquidity risk of the tranche. The spreads on the floating rate European securitized bonds in our sample are quoted exclusively over LIBOR or EURIBOR.

Following, Cuchra (2005) and He et al. (2012), we do not include the reference rates in the initial spread to avoid incorporating a systematic component into our results. Theoretically, the benchmark rates are not risk-free rates. They are essentially spreads over the risk free rate to proxy for the relevant maturity. However, prior to the summer of 2007, the EURIBOR and the LIBOR were largely viewed as suitable proxies for the risk free rates because spreads between these benchmark rates and the corresponding overnight rates were considered to be negligible and insignificant ${ }^{10}(\mathrm{ECB}$, 2013, 2014; Grbac and Runggaldier, 2015). Due to the increased counterparty risk as well as funding hurdles during the onset of the financial crisis, these reference rates increasingly began to reflect the credit risk and liquidity risk of the interbank sector (Grbac and Runggaldier, 2015). Following Fabozzi

\footnotetext{
${ }^{10}$ Spreads between EURIBOR and LIBOR were virtually zero until August 2007. The spreads widened and peaked after 15 th September 2008 when the Lehman Brothers declared bankruptcy.
} 
and Vink (2012a), we also restrict our sample to tranches issued at par to preclude distortions of discounts or premiums on the actual yield spreads. This results in a final sample of 4,201 tranches from 730 deals.

\subsection{Empirical model}

The baseline model for explaining the primary yield spread is specified as follows where the data vary by tranche $(d)$, trustee $(k)$ and time $(t)$ :

$$
\begin{aligned}
\text { LogSpread }_{d, k, t} & =\beta_{0}+\beta_{1} \text { Trustee Reputation }_{k}+\beta_{2} \text { Pre-crisis Period }_{t}+\beta_{3} \text { Distance }_{d, t} \\
+ & \beta_{4} \text { Retained }_{d, t}+\beta_{5} \text { Ratings }_{\text {Tranches }}, t+\beta_{6} \text { Credit Rating Agencies }_{d, t} \\
& +\beta_{7} \text { Subordination }_{d, t}+\beta_{8} \text { Size }_{d, t}+\beta_{9} \text { Weighted Average Life }_{d, t} \\
& +\beta_{10} \text { Step-up tranche } \\
d, t & +\beta_{11} \text { Collateral }_{d, t} \\
& + \text { Tranche Credit Rating, Country,Trustee, Issuer, and Time controls }+e_{d, k, t}
\end{aligned}
$$

We explain the dependent and explanatory variables of the model below.

LogSpread represents the natural logarithm of the initial yield spread quoted as a fixed premium in basis points over the relevant benchmark rate. Initial spread is a more reliable indicator of the actual offer price and risk premiums demanded by the market at the issuance.

Trustee Reputation is measured with two alternative variables. Trustee Share, a continuous variable, is the number of deals a trustee has been assigned to as a fraction of the number of all deals issued in the previous year. ${ }^{11}$ Trustee Top5 is a dummy variable that takes the value of 1 if the trustee is one of the top five trustees in terms of total market volume during this period, and 0 otherwise. Top five trustees constitute $51.2 \%$ of all deals in our sample. We expect lower spreads on deals with reputable trustees as they are more likely to be more effective debt monitors.

Pre-crisis Period is a set of dummy variables that proxy for the credit boom period; for the years 2005 ( 1 if 2005 and 0 otherwise), 2006 ( 1 if 2006 and 0 otherwise) and 2007 ( 1 if 2007 and 0 otherwise). This variable controls for the impact of the increase in the securitization activity volume in the market during this period. We interact trustee reputation variables with Pre-crisis year dummy variables to determine whether the influence of trustee market share varied significantly during the

\footnotetext{
${ }^{11}$ Trustees are typically appointed based on reporting quality and fee considerations. Their capability of handling the documentation review process is also a key criterion in tendering process. Large trustees typically increase their market presence by acting as one-stop shops for fiduciary and agency functions. These institutions are authorised to alter documentation terms and correct manifest errors (Choudhry,2013).
} 
boom period. Following the intuition of (Carbo-Valverde et al., 2015; He et al., 2016), we also use an alternative variable Boom - a dummy variable that takes a value of 1 if a deal is issued in the years from 2005 to 2007 and 0 otherwise.

In order to understand factors that investors incorporate into the price of MBS, it is important to first take into account the generic factors considered by ratings agencies as a starting point. If credit ratings capture these factors accurately then they should have no explanatory power in our empirical analysis. Although all agencies have a relatively different credit rating methodology, their individual approaches tend to cover three main areas: asset analysis, structural analysis and counterparty risk analysis (Fabozzi and Vink, 2012b). These authors also note that majority of defaults have rarely been as a result of counterparty risk. The risk profile of a structured bond is therefore largely a function of the collateral, structural factors and the tranche's maturity (Whetten and Adelson, 2004).

\subsubsection{Control Variables}

We construct Distance, a dummy variable that takes the value of 1 if the nationality of the originator's parent differs from the country of origination and 0 otherwise. Information based theories of banking (Stein, 2002; Mian, 2006; Detragiache et al., 2008; Berger et al., 2008) suggest that foreign banks face informational difficulties when assessing credit applications from local borrowers, especially opaque ones. Therefore, they tend to focus on observables (hard information) when granting credit as this type of information is easier to come by. However, in their theoretical model on securitization and lending competition, Frankel and Jin (2015) argue that despite the relative informational disadvantage of foreign banks, securitization enhances competition for borrowers with strong observables (favourable hard information - e.g. credit score, loan-to-value ratio). Thus, these banks tend to make worse lending decisions because they lack or possess relatively limited soft information (e.g. borrower's job, income stability). In fact, Loutskina and Strahan (2011) find empirical evidence suggesting that geographical diversification led to a decline in screening incentives as securitization volumes surged. Consequently, we expect the spreads on MBS issued by foreign banks to be higher.

Decisions on tranching are taken depending on a number of factors including desired credit rating, expected client base, and market segmentation. Due to the different levels of priority with regard to the cash flow/loss distribution, tranches carry different levels of risk and different credit ratings. Investors with different risk appetites can decide which tranche is suitable for their preference. For instance, due to regulatory requirements, institutional investors, such as pension funds, are typically interested in holding the highest rated tranches. As expressed in (Boot and Thakor, 1993), tranching 
ranks cash flows into informationally insensitive securities (i.e. safe assets) and informationally sensitive tranches (i.e. riskier assets). In practice, tranches are usually classified into senior, mezzanine and equity tranches where the equity tranche is the first to absorb credit losses. The equity tranche is highly leveraged while the senior tranche is unleveraged. Tranching essentially relegates investment risk into the lower informationally sensitive tranches, with a fundamental objective of determining a minimum subordination level that will render the senior security riskless. Furthermore, relative to investors, the issuer has more information about the mortgage pool. Therefore the retention of a risky tranche minimises the lemons discount (Riddiough, 1997). Retained tranches are essentially credit enhancement devices to shield investors from the effects of the originator's perverse incentives (Franke et al., 2012). ${ }^{12}$ In our dataset, we know of deals where the issuer retained at least one tranche; however, it is unclear which tranche was retained. We use Retained to proxy for tranche retention within a deal. This is a binary deal level variable which is set to 1 if at least one tranche is retained and 0 otherwise.

Because of the advancement in structuring techniques, the true structure and cash flows in different states of the economy have become complex and opaque. There are two prominent views on the complexity of structured bonds (Ghent et al., 2017). On the one hand, if the primary objective of structuring is to generate low risk securities from variable quality collateral, then complexity is just a natural consequence of structuring. In this case, deals backed by low quality collateral feature more intricate and complicated structures. However, the quality of the underlying collateral is not necessarily negatively related to the default of the securities. On the other hand, complexity can be used as a strategic device to obscure the true quality of an asset, thereby deliberately making the due-diligence process cumbersome for investors. Following Ghent et al. (2017), we measure complexity as a deal level variable denoting the amount of information investors need to process to arrive at the true value of a tranche. As in their empirical model, a number of studies (He et al., 2016; He et al., 2012; Furfine, 2014) have used the number of tranches in a deal to proxy for complexity. Using data on European MBSs, Cuchra and Jenkinson (2005) note that the creation of additional tranches with distinct ratings resulted in increased informationally sensitive tranches compared to further tranching within the same rating class. Therefore, we refine our complexity measure by computing Ratings/Tranches as the ratio of number of unique ratings in a deal to the total number of tranches in a deal.

\footnotetext{
${ }^{12}$ Further evidence suggests that equity retention maximises originators' screening effort (Kiff and Kisser, 2014) and minimises information loss (Guo and $\mathrm{Wu}, 2014)$. However, (Kuncl, 2015) show that although retention aligns originator and investor interests, the efficiency of this device is limited especially during economic booms.
} 


\subsubsection{Credit Ratings}

The securitization pricing literature overwhelmingly concurs that credit ratings explain substantial variation in initial yields. For instance, Fabozzi and Vink (2012a) find that credit ratings explain 74\% of the variation in the yields of UK RMBSs. Other papers such as Cuchra (2005) and Fabozzi and Vink (2012b) find similar evidence. This is expected since MBSs are typically structured by underwriters in consultation with rating agencies to achieve a specific rating.

In practice, many issuers elect to secure or report more than one credit rating on each debt obligation. This could be because of investment guidelines for certain institutional investors or regulatory requirements for certain issues to have at least two ratings. In addition, Standard \& Poors (S\&P) and Fitch ratings measure probability of default while Moody's ratings, by contrast, measure expected losses. Therefore some issuers perceive that securing a Moody's rating and an S\&P/Fitch rating may provide additional information with regards to credit worthiness (Güntay and Hackbarth, 2010; Fabozzi and Vink, 2015).

Issuers have the latitude to choose which ratings to purchase. These choices allow issuers to selectively report only the highest rating while potentially neglecting unfavourable preliminary ratings. Based on a sample of privately issued MBS, He et al. (2012) show that the rating shopping hypothesis [as modelled by Skreta and Veldkamp (2009); Sangiorgi et al. (2009)] was priced by investors into initial yields. The authors find that yields were highest on single rated tranches and least on tranches rated on all three agencies. Rating shopping is not the primary focus of our paper; however, we have controlled for this phenomenon as there is existing evidence that investors factored it into initial yields. We control for rating shopping ${ }^{13}$ with Credit Rating Agencies, the number of initial ratings reported for each tranche. Issuers are not required to report all ratings; however, ratings from all three agencies suggest more transparency while ratings from either one or two may indicate suppression of negative ratings.

Deals in our sample are rated by at least one of the three major ratings agencies (S\&P, Moody's or Fitch). ${ }^{14}$ Dealogic reports a composite credit rating that combines the credit ratings from different ratings agencies for each tranche. The use of composite credit ratings is quite common in the corporate bond literature (Campbell and Taksler, 2003) as well as in the securitization literature (Fabozzi and

\footnotetext{
${ }^{13} \mathrm{He}$ et al. (2012) include the number of initial ratings as well as ratings disagreements in their analyses. We find these variables to be highly collinear. However, the influence of ratings disagreements is beyond the scope of our paper.

${ }^{14}$ Based on turnover in 2014, S\&P, Moody's and Fitch controlled $91.89 \%$ of the credit ratings sector in the EU (ESMA, 2015).
} 
Vink, 2015). We map the composite ratings onto a numerical scale where $\mathrm{AAA}=1, \mathrm{AA}+=2$ and $\mathrm{AA}=3$ and so on ${ }^{15}$ for the sample descriptive statistics. We categorise AAA/Aaa rated bonds as prime and bonds with other ratings as non-prime. Tranche Credit Rating is coded as a factor variable to control for each distinct rating.

Ratings agencies use different methods and various criteria in determining credit ratings of securitized mortgage bonds. Some of the components of assessed risks may be tranche specific while others may be deal specific. Changes in deal specific risk factors tend to trigger deal wide rating revisions. It is therefore unlikely that tranches within a specific deal are independent of each other. For instance, the ratings on multiple tranches tend to be modified around the same time (Adelino, 2009). Therefore, we cluster standard errors at the deal level to mitigate correlation of errors within deals (Cuchra, 2005).

\subsubsection{Structural factors}

Credit enhancements are techniques used in structuring MBSs in order to increase the credit quality of the bonds and achieve favourable ratings. An MBS issuer consults credit ratings agencies to ascertain the required levels of credit enhancement necessary for the issue to attain the desired credit ratings. The most common form of credit enhancement is subordination in which deals follow a senior/subordinate structure. Subordinated tranches absorb losses before senior tranches do. The subordinate tranches are more exposed to credit losses from the underlying collateral; consequently, senior tranches receive higher ratings but lower returns. This variable features as a common control variable in the securitization literature (He et al., 2016; Fabozzi and Vink, 2012b; He et al., 2012). We compute the Subordination for each tranche in our sample. This variable is computed as the value of tranches in the same deal that have an equal or higher rating than the given tranche as a fraction of the total deal value. As our main measure of deal structure, this variable proxies for the credit support offered by lower tranches in each deal. As Whetten and Adelson (2004) note, subordination levels and tranche sizes determine how the risk of the collateral is redistributed among tranches. Subordination levels indicate the absolute risk levels for each tranche while size ${ }^{16}$ defines tranche liquidity. We control for tranche sizes using Size, which we compute as the natural logarithm of the principal value of the relevant tranche.

\footnotetext{
${ }^{15}$ We map the composite ratings onto a numerical scale where $\mathrm{AAA}=1, \mathrm{AA}+=2, \mathrm{AA}=3, \mathrm{AA}-=4, \mathrm{~A}+=5, \mathrm{~A}=6, \mathrm{~A}-=7, \mathrm{BBB}+=8, \mathrm{BBB}=9, \mathrm{BBB}-=10$, $\mathrm{BB}+=11, \mathrm{BB}=12, \mathrm{BB}-=13, \mathrm{~B}+=14, \mathrm{~B}=15, \mathrm{~B}-=16, \mathrm{CCC}+=17, \mathrm{CCC}=18, \mathrm{CCC}-=19$ and $\mathrm{CC}=20$.

${ }^{16}$ Smaller deals have fewer tranches and Cuchra (2005) attribute this to issuers' goal of fostering liquidity on the secondary market. However, Schaber (2008) argues that this trend is due to the cost inefficiency associated with marketing and research efforts by originators and investors respectively.
} 
Rather than nominal maturity, issuers tend to place more emphasis on the weighted average $\operatorname{life}^{17}$ of the securitized bonds. Unlike nominal maturity, weighted average life is a composite metric of effective maturity that incorporates appropriate prepayment assumptions. Therefore, the weighted average life in years will always be shorter than the nominal maturity of a mortgage backed security. There is ample evidence indicating that weighted average life is a major determinant of launch spreads (Cuchra, 2005; Cuchra and Jenkinson, 2005; He et al., 2016; He et al., 2012). Consequently, we control for effective maturity using the Weighted Average Life (as reported by Bloomberg) for each tranche.

Although all the MBSs in our sample are floating rate notes, a number of bonds are structured as step-up bonds where the offered spread at issuance resets after a given period. We control for this using a dummy variable, Step-up tranche, which takes the value of 1 if the relevant MBS is a step-up note and 0 otherwise.

\subsubsection{Asset factors}

Asset analysis involves evaluating the quality of collateral underlying the deal. This quality differs across countries and issuers. Our sample contains tranches backed by two distinct types of collateral as residential and commercial mortgages. When rating RMBSs, agencies devote more attention to underwriting standards and historical loss data. However, the focus of agencies when rating CMBSs is the income earning capacity of the property (Kothari, 2006). Therefore, due to the differing risk profiles of both types of securities, it is expected that the pricing considerations of RMBS differ from those of CMBS. Consequently, we use Collateral as a dummy variable that takes the value of 1 for RMBS and 0 for CMBS.

Fabozzi and Vink (2012b) provide empirical evidence underscoring the importance of country of origination as an essential consideration for pricing securitized bonds. The authors also show that credit ratings agencies lay emphasis on the country of origination as this can greatly influence the performance of the securities owing to variations in macroeconomic conditions, legal systems, cash flow currencies and origination standards. Prepayment patterns tend to be a function of country of origination and the overall profile of the collateral (Cuchra, 2005). In general, countries with expected unfavourable economic conditions warrant more conservative assumptions in generating credit ratings.

\footnotetext{
${ }^{17}$ According to Cuchra (2005) nominal maturity is less meaningful for securitization issues because weighted average life incorporates essential modelling factors such as prepayment assumptions, embedded options and expected repayment speed of the underlying assets. In contrast with corporate bonds, the nominal maturity of MBSs is unrelated to the expected date of principal repayment.
} 
To this effect, we control for country risk by including country fixed effects in all specifications to capture geographically induced variations respectively.

We employ a fixed effects model where time (issuance-time) and issuer and trustee effects are conditioned out in order to account for issuer and trustee specific attributes. On the one hand, pooled cross-sectional data has the advantage of increasing the sample size, which in turn improves the precision of estimators assuming that the relationships being estimated are temporally stable. However, this assumption may be too strict and time dummy variables can be used to allow for some variation over time (Wooldridge, 2013). Also, since we use pooled cross-sectional data, the distribution of our independent variables may change over time and tranches within a given year may be affected by the same macroeconomic conditions. We introduce time (year) dummy variables to capture the net effect of all time varying factors (Petersen, 2009; Fabozzi and Vink, 2015). We do not explicitly control for macroeconomic conditions as the time dummy variables capture the effect of unobserved systematic period effects. In addition, including time dummy variables allows us to interact them with other key variables to determine whether these variables have changed over time.

On the other hand, it is infeasible to control for all variables that influence yield spreads and our model is susceptible to an omitted variable bias. We deal with this shortcoming by characterizing possible unobserved variables, the most common of which is a fixed effect - time-invariant characteristics of issuers and trustees in our sample. We address the omitted variable bias by explicitly including dummy variables for each cross sectional unit, in other words, for each issuer and each trustee. These dummy variables should absorb the individual effects of the issuers and trustees.

\subsection{Descriptive statistics}

We present the sample characteristics statistics in Table 1. Panel A shows the distribution of the sample according to rating categories and underlying collateral. The collaterals within the data are split into residential (RMBS, 81.81\%) and commercial (CMBS, 18.19\%) categories. Based on the composite rating, the sample comprises 1,568 (37.32\%) prime tranches and 2,633 (62.68\%) non-prime tranches. Panel B shows that a large number of tranches receive multiple ratings $(51.06 \%$ and $42.80 \%$ for 3 and 2 ratings, respectively) while only $6.14 \%$ of tranches are solely rated. Panel C shows top 5 trustees and top 10 issuers based on number of deals. The trustee market seems rather concentrated as the top 5 trustee banks were party to $51.23 \%$ of all deals issued. 
In Table 2, we categorise the tranches into cohorts based on rating category and country of collateral (country of risk). $54.8 \%$ of all tranches are based on assets originated in the UK, followed by Spain $(13.12 \%)$ and Netherlands (8.97\%). These three countries account for $76.89 \%$ of the tranches in our sample.

In Table 3, we present the descriptive statistics for the aggregate sample. The mean spread is 66.18 basis points (bps) for the full sample compared to 62.55 bps for RMBSs and 82.46 bps for CMBSs. RMBS deals, averaging approximately $€ 2.17$ billion, are more than twice the size of an average CMBS deal (€768 million). Similarly, RMBS tranches are 1.79 times larger than CMBS tranches suggesting that RMBS issues contain relatively more tranches per deal. RMBS deals have an average of 9.29 tranches per deal and at least 4 distinct rating categories while CMBS deals typically contain 6.64 tranches with 5.19 unique rating groups. The median rating for the whole sample is 4.00 which corresponds to AA-.

\section{Regression Results}

We estimate our models progressively. First, we present the results for the full sample. Subsequently, we split the sample into two groups as prime (AAA rated) tranches and non-prime (non-AAA rated) tranches according to risk categories to examine whether reputational effects differ depending on the level of risk taken by the investors.

\subsection{Trustee reputation variables}

Results for the full sample are presented in Table 4 in six columns. We first employ Trustee Top5 only (in column 1) and find that it has an insignificant coefficient. This implies that the reputation of trustees had no impact on spreads. It is consistent with the prevalent view in the literature that investors perceive trustees as ineffective monitoring devices (Amihud et al., 2000; Schwarcs and Sergi, 2008; Bavoso, 2015; Spiotto, 2012).

Before introducing the interactions with the year dummy variables, it is worth noting the impact of the pre-crisis period (2005-2007) on initial yield spreads of MBSs. We find consistently significant and negative coefficients for the year dummy variables for the pre-crisis years (base year is 2000). Initial yields gradually declined during these years. European securitization activity soared between 2005 and 2007 and this period corresponds to highest activity values in our sample. These results capture the decline in return on financial assets due to general credit cycle conditions during this period. 
We introduce Trustee Top5's interaction with the pre-crisis period (Boom) in column 2 of Table 4. We find Trustee Top5 $\times$ Boom to be statistically significant and negative. This indicates that investors started to perceive reputable trustees to be more effective debt monitors as the volume of issuance increased in the credit boom period before the financial crisis. Investors may have assumed that trustees were relatively passive parties in MBS deals in general. However, it seems that during the progressive phase of the credit expansionary period, investors started to rely on reputable trustees, as more effective debt monitors, to shield them from possible increasing risks in MBS deals. The negative spreads are consistent with the reputation buying effect identified by (Carbo-Valverde et al., 2015). They study the certification effect of underwriters of bank debt from 2003 to 2013 and find evidence of reputation discounts and these discounts increased significantly during the crisis period.

We subsequently interact Trustee Top5 with each of the year variables for the pre-crisis credit expansionary period $(\mathbf{2 0 0 5}, 2006$ and 2007) in column 3 . We find that all of the coefficients for Trustee Top5 × 2005, Trustee Top5 × 2006 and Trustee Top5 x 2007 are significant and the size of the coefficient increased as the financial crisis loomed. This shows that as the credit markets expanded rapidly between 2005 and 2007, investors perceived trustee reputation to be increasingly important in mitigating possible MBS risks.

We follow a similar approach in employing Trustee Share and interacting it with pre-crisis year dummy variables in columns 4 to 6 of Table 4. We find that Trustee Share is negatively related to spreads and is statistically significant (column 4). Different from the dummy trustee reputation proxy (Trustee Top5) this finding shows that investors perceived trustees as effective monitoring devices. However, when we interact Trustee Share with Boom and pre-crisis year dummy variables the coefficient of Trustee Share becomes statistically insignificant. In contrast, and similar to results reported above, all of the coefficients for Trustee Share x Boom (column 5), Trustee Top5 x 2005, Trustee Top5 x 2006 and Trustee Top5 x 2007 (column 6) are significant. We also observe that the coefficients for the latter two variables are significantly larger. Overall, we find similar results with our two alternative trustee reputation indicators.

\subsection{Other variables}

Out of the three main control variables, only Distance is statistically significant in all models. This provides some evidence that, consistent with our expectations, investors value local issuer expertise, where it is expected that domestic banks would be more specialised due to their familiarity with the local market. Thus, they are more likely to detect borrower misrepresentation and extend safer loans. 
Retained is not significant in any of the specifications. Retention as an alignment device seems to have lost its importance since it does affect issuers' borrowing costs. Ratings/Tranches is weakly significant but only in some of the models.

We observe that the number of rating agencies associated with a deal is a significant predictor of spreads. Using spreads on MBSs rated by all three agencies as the reference category, initial yields on notes rated by two agencies were between $6 \%$ to $8 \%$ higher, while the premium on those rated by one agency ranged from $12 \%$ to $14 \%$. Our cautious interpretation is that investors incorporate the value of rating triangulation into the pricing process. Reported ratings from all three agencies suggest more transparency while ratings from either one or two may indicate suppression of negative ratings.

Subordination is strongly significant in all of the models and it seems that credit ratings do not completely capture the leverage effects within deals and subordination signals generally higher risk deals. Weighted Average Life is a key determinant of initial spreads as this variable is significant and consistently positive in all specifications in Table 4. This finding is consistent with Cuchra (2005), where launch spreads were persistently positively related to effective maturity. Liquidity, proxied by Size, is not significant in any of the specifications.

With regards to collateral, spreads on RMBS notes were at least $12 \%$ lower than initial funding costs associated with CMBS notes. This is consistent with our expectations as commercial mortgages are larger, less regulated and attract more risk weighting. Also, there is comparatively less competition in the commercial mortgage market hence the prices of these mortgages are higher compared to the prices of residential mortgages.

\subsection{Prime versus non-prime tranches}

We split the sample into prime (AAA rated) and non-prime (non-AAA rated) subsamples to test the impact of trustee reputation on spreads under different risk levels. Existing literature argues that investors do not solely rely on credit ratings and shows that they consider other indicators (such as issuer reputation, rating bias and creditor protection) that were already incorporated in credit ratings when pricing MBSs (Fabozzi and Vink, 2012a). Here we aim to examine whether investor behaviour changes depending on the risk level of the tranches.

We present the results for the Trustee Top5 in Table 5 for prime (columns 1 to 3 ) and nonprime (4 to 6) tranches. Our findings for the two sub-samples are very similar to the results reported above for the main sample. We find that Trustee Top5 is insignificant for both sub-samples. We also 
find that all Trustee Top5 and pre-crisis years interaction variables are statistically significant with similar size coefficients. It seems that investors generally perceive trustees as ineffective debt monitors for all MBS tranches regardless of risk levels. They incorporate the value of reputable trustees into yields but only during the periods of increased market activity. We present the results for the Trustee Share in Table 6 for prime (columns 1 to 3) and non-prime (4 to 6) tranches. We find that Trustee Share is significant for both sub-samples when employed without the interaction variables; however, the coefficients for this variable lose their significance when interaction variables for the pre-crisis years are introduced into the model. We consistently find that during the pre-crisis period, investors valued trustee reputation, regarding trustees as efficient monitors during risky periods.

Turning to the other variables, in Tables 5 and 6, we find that the rating shopping (Credit Rating Agencies) variables are mostly insignificant for AAA tranches. Investors do not seem to be sceptical when tranches are rated AAA and the involvement of multiple rating agencies in deal structuring seems to be of little importance to AAA investors. This finding resonates with the argument that the demand for collateral fed into the demand for high-quality asset-backed securities (Gorton and Metrick, 2012b). On the other hand, Credit Rating Agencies remains positive and highly significant in all specifications for the non-prime sample. Unlike investors of prime tranches, investors of nonprime tranches discounted the required yields as the number of agencies increased. This is not surprising as it is less likely that issuers, regardless of size, can influence all three rating agencies to report favourable ratings only. Reporting ratings from two agencies does not necessarily mean that the unfavourable ratings from a third agency have been suppressed. However, using notes rated by three agencies as the base, we find that yields on non-prime tranches rated by two agencies are $5 \%$ to $7 \%$ higher while spreads on those rated by just one agency were around $18 \%$ to $19 \%$ higher. We find that Rating/Tranches variable is strongly significant and positively related to spreads for the prime sample only. This variable captures the number of information sensitive categories within a deal. Thus, spreads are higher for AAA rated tranches in deals with more information sensitive tranches.

Similar to the full sample, we find some significance for the Distance variable; however, this finding is confined to prime tranches. Therefore, even though investors of prime tranches may have overly relied on credit ratings, they demanded higher yields when foreign banks originated the underlying assets. The size and significance of coefficients for Weighted Average Life show similar patterns for both prime and non-prime samples; however, coefficients are much larger in the prime sample. Size, on the other hand, is only significant for prime tranches and carries a negative sign. This 
means that investors of prime tranches demand lower liquidity premiums and higher maturity premiums.

\section{Conclusion}

We consider the role of trustees - who are nominated to protect the interests of investors - in securitization pricing and whether investors rely on them to mitigate risks. There is a growing literature showing that investors attempted to incorporate the potential costs of misaligned interests in the yields of securitization products in the pre-crisis period. We contribute to this literature by investigating whether investors factored trustee reputation into the valuation of MBSs. We do this by examining the effect of reputation on primary spreads of MBSs using a large sample of rated European securitization issuances between 1999 and the first half of 2007.

We find that hiring reputable trustees led to lower spreads during the credit boom period prior to the 2007-2009 financial crisis. Furthermore, the importance of reputable trustees for risk mitigation increased gradually as the financial crisis loomed. Overall, our findings suggest that the reputation of trustees was regarded as a critical yardstick, as risk assessment became more difficult. Thus, investors began to associate trustee reputation with effective debt monitoring as the concern for defaults grew in boom periods. We also show that although investors incurred substantial losses during the financial crisis, they did not exclusively rely on credit ratings. They took steps to protect their investments, however inadequate, by adjusting the valuations of the structured notes they purchased.

The role of the trustee may be a passive one, especially with respect to breaches. However, it is unclear whether investors initially appreciated how passive the trustee's role was. In an attempt to revive and reform securitization, regulators have proposed the inclusion of another third party, an independent reviewer, into the securitization chain. Public comments on early drafts of Regulation $\mathrm{AB}$ (SEC, 2014) revealed that investors and other stakeholders were against allocating this role to trustees due to concerns about affiliations with other parties such as servicers. Investors have clearly outlined their frustrations against trustees and it is unclear whether these sentiments persist. Therefore, consistent with the proposal of Regulation $\mathrm{AB}$, trustees should not be in the position of appointing independent credit reviewers as this might compound investor concerns about conflicting interests.

The US banking industry's trade association argues that trustees were not complicit in the deteriorating quality of MBSs during the financial crisis (ABA, 2010). They stress that although the responsibilities of trustees in MBS transactions exceed those embedded in conventional corporate debt 
transactions, the request for compensation from trustees is evidence that market participants have clearly misinterpreted the remit of trustees. In this regard, responsibilities of the trustees should be clearly outlined to avoid further misinterpretation. Recent policy changes in the European Securitization market may have remedying implications on some of the issues highlighted above. We expect that the implementation of the EU framework on Simple, Transparent, and Standardised (STS) Securitizations should limit, possibly eliminate, and spread variation due to issuer and trustee reputation. 


\section{Table 1}

Sample characteristics

Panel A: Tranche distribution by rating categories and underlying collateral

\begin{tabular}{lcccr} 
Collateral & Prime & Non-Prime & Total & Percentage \\
\hline Commercial mortgages & 219 & 545 & 764 & $18.19 \%$ \\
Residential mortgages & 1,349 & 2,088 & 3437 & $81.81 \%$ \\
\hline Total & 1,568 & 2,633 & 4,201 & $100.00 \%$ \\
\hline Percentage & $37.32 \%$ & $62.68 \%$ & & \\
\hline
\end{tabular}

Panel B: Tranche distribution by number of ratings secured

\begin{tabular}{lcccr}
\hline No. of Ratings & RMBS & CMBS & Total & Percentage \\
\hline 1 & 218 & 40 & 258 & $6.14 \%$ \\
2 & 1,277 & 521 & 1,798 & $42.80 \%$ \\
3 & 1,942 & 203 & 2,145 & $51.06 \%$ \\
\hline Total & 3,437 & 764 & 4,201 & $100.00 \%$ \\
\hline
\end{tabular}

Panel C: Top issuing and trustee banks (number of deals)

\begin{tabular}{lclc}
\hline \multicolumn{1}{c}{ Issuing Banks } & Percentage & \multicolumn{1}{c}{ Trustee Banks } & Percentage \\
\hline Lehman Brothers Holdings Inc. & $4.90 \%$ & Stichting Security & $12.86 \%$ \\
Ally Financial Inc & $4.39 \%$ & Bank of New York & $11.94 \%$ \\
Morgan Stanley & $3.37 \%$ & JPMorgan Chase \& Co. & $9.90 \%$ \\
Barclays Bank Plc & $2.96 \%$ & Deutsche Bank & $8.88 \%$ \\
Royal Bank of Scotland Group Plc & $2.76 \%$ & Capita Plc & $7.65 \%$ \\
NRAM PLC & $2.55 \%$ & & \\
Kensington Group Plc & $2.35 \%$ & & \\
Credit Suisse AG & $2.24 \%$ & & \\
Commerzbank AG & $2.14 \%$ & & \\
Banco Santander SA & $2.04 \%$ & & $51.23 \%$ \\
Deutsche Bank AG & $2.04 \%$ & & \\
HBOS Plc & $2.04 \%$ & & \\
& $33.78 \%$ & & \\
\hline
\end{tabular}


Table 2

Country of issuance

\begin{tabular}{|c|c|c|c|c|c|c|c|c|}
\hline \multirow[b]{2}{*}{ Country of Risk } & \multicolumn{3}{|c|}{ RMBS } & \multicolumn{3}{|c|}{ CMBS } & \multicolumn{2}{|c|}{ All Issues } \\
\hline & Prime & $\begin{array}{l}\text { Non- } \\
\text { Prime }\end{array}$ & Total & Prime & $\begin{array}{l}\text { Non- } \\
\text { Prime }\end{array}$ & Total & Frequency & Percentage \\
\hline United Kingdom & 757 & 1,092 & 1,849 & 132 & 321 & 453 & 2,302 & $54.80 \%$ \\
\hline Spain & 213 & 332 & 545 & 2 & 4 & 6 & 551 & $13.12 \%$ \\
\hline Netherlands & 118 & 250 & 368 & 2 & 7 & 9 & 377 & $8.97 \%$ \\
\hline Germany & 48 & 109 & 157 & 54 & 139 & 193 & 350 & $8.33 \%$ \\
\hline Italy & 122 & 154 & 276 & 15 & 31 & 46 & 322 & $7.66 \%$ \\
\hline Portugal & 24 & 57 & 81 & & & & 81 & $1.93 \%$ \\
\hline Ireland & 37 & 34 & 71 & 1 & 3 & 4 & 75 & $1.79 \%$ \\
\hline France & 11 & 9 & 20 & 12 & 34 & 46 & 66 & $1.57 \%$ \\
\hline Greece & 8 & 17 & 25 & & & & 25 & $0.60 \%$ \\
\hline Sweden & 5 & 9 & 14 & 1 & 6 & 7 & 21 & $0.50 \%$ \\
\hline Belgium & 5 & 13 & 18 & & & & 18 & $0.43 \%$ \\
\hline Russian Federation & & 9 & 9 & & & & 9 & $0.21 \%$ \\
\hline Switzerland & 1 & 1 & 2 & & & & 2 & $0.05 \%$ \\
\hline Ukraine & & 2 & 2 & & & & 2 & $0.05 \%$ \\
\hline Total & 1,349 & 2,088 & 3,437 & 219 & 545 & 764 & 4,201 & $100.00 \%$ \\
\hline Percentage & & & $81.81 \%$ & & & $18.19 \%$ & & $100.00 \%$ \\
\hline
\end{tabular}


Table 3

Descriptive statistics

\begin{tabular}{|c|c|c|c|c|c|c|}
\hline Variable & Type & $\mathrm{N}$ & Mean & Median & Std. Dev & $\mathrm{p} 75$ \\
\hline \multirow{3}{*}{ Spread (basis points) } & RMBS & 3,437 & 62.55 & 30.00 & 87.86 & 65.00 \\
\hline & CMBS & 764 & 82.46 & 48.00 & 99.76 & 86.00 \\
\hline & Total & 4,201 & 66.18 & 34.00 & 90.46 & 72.00 \\
\hline \multirow{3}{*}{$\begin{array}{l}\text { Weighted Average Life } \\
\text { (years) }\end{array}$} & RMBS & 3,437 & 5.33 & 4.99 & 3.21 & 6.90 \\
\hline & CMBS & 764 & 5.99 & 6.00 & 1.86 & 7.00 \\
\hline & Total & 4,201 & 5.45 & 5.07 & 3.02 & 6.95 \\
\hline \multirow[t]{3}{*}{ Credit Rating } & RMBS & 3,437 & 4.68 & 3.00 & 3.89 & 9.00 \\
\hline & CMBS & 764 & 4.95 & 4.00 & 3.68 & 9.00 \\
\hline & Total & 4,201 & 4.73 & 3.00 & 3.86 & 9.00 \\
\hline \multirow[t]{3}{*}{ Number of Ratings } & RMBS & 3,437 & 4.00 & 4.00 & 1.27 & 5.00 \\
\hline & CMBS & 764 & 5.19 & 5.00 & 1.33 & 6.00 \\
\hline & Total & 4,201 & 4.21 & 4.00 & 1.36 & 5.00 \\
\hline \multirow[t]{3}{*}{ Number of Tranches } & RMBS & 3,437 & 9.29 & 7.00 & 5.85 & 14.00 \\
\hline & CMBS & 764 & 6.64 & 6.00 & 2.20 & 8.00 \\
\hline & Total & 4,201 & 8.81 & 7.00 & 5.47 & 13.00 \\
\hline \multirow[t]{3}{*}{ Ratings/Tranches } & RMBS & 3,437 & 0.59 & 0.60 & 0.30 & 0.83 \\
\hline & CMBS & 764 & 0.79 & 0.80 & 0.17 & 1.00 \\
\hline & Total & 4,201 & 0.62 & 0.67 & 0.29 & 0.83 \\
\hline \multirow[t]{3}{*}{ Subordination } & RMBS & 3,437 & 0.06 & 0.05 & 0.08 & 0.09 \\
\hline & CMBS & 764 & 0.16 & 0.13 & 0.15 & 0.23 \\
\hline & Total & 4,201 & 0.08 & 0.05 & 0.10 & 0.10 \\
\hline \multirow[t]{3}{*}{ Tranche Value (€ million) } & RMBS & 3,437 & 244.00 & 45.60 & 479.00 & 255.00 \\
\hline & CMBS & 764 & 136.00 & 53.10 & 202.00 & 135.00 \\
\hline & Total & 4,201 & 224.00 & 47.50 & 444.00 & 227.00 \\
\hline \multirow[t]{3}{*}{ Deal Value ( $€$ million) } & RMBS & 3,437 & $2,170.00$ & $1,110.00$ & $2,390.00$ & $2,630.00$ \\
\hline & CMBS & 764 & 768.00 & 661.00 & 440.00 & 970.00 \\
\hline & Total & 4,201 & $1,910.00$ & $1,010.00$ & $2,240.00$ & $2,000.00$ \\
\hline \multirow[t]{3}{*}{ Trustee Share } & RMBS & 3,395 & 0.09 & 0.09 & 0.05 & 0.12 \\
\hline & CMBS & 764 & 0.07 & 0.06 & 0.04 & 0.09 \\
\hline & Total & 4,159 & 0.08 & 0.08 & 0.05 & 0.11 \\
\hline
\end{tabular}




\section{Table 4}

The impact of trustee reputation on initial yield spreads of MBS tranches

This table reports OLS regressions of the log of initial yield spread (logspread) of European MBS tranches on trustee reputation, deal, collateral and tranche-level characteristics. The sample includes all rated floating tranches issued between 1999 and June 2007. Trustee Share is the number of deals a trustee has been assigned to as a fraction of the number of all deals issued in the previous year. Trustee Top 5 is a dummy variable that takes the value of 1 if the trustee is one of the top five trustees in terms of total market volume during this period, and 0 otherwise. Boom equals to 1 if a deal is issued in the years from 2005 to 2007 and 0 otherwise. Ratings/Tranches is the ratio of number of distinct rating classes within a deal divided by number of tranches per deal. Retained is a dummy variable equals 1 if a tranche in the relevant deal is retained. Distance is a dummy variable equals 1 if an issuer's nationality of operations differs from the home country of the parent institution. Credit Rating Agencies is the number of initial ratings reported for a tranche. Subordination is the value of tranches with an identical or a better rating as a fraction of the total deal value. Step-up tranche is a dummy variable equal to 1 if the spread quoted at issuance is adjusted upwards on a specified future date and 0 otherwise. Weighted Average Life is the natural logarithm of the mean number of years the principal value of a tranche remains unpaid. Size is the natural logarithm of tranche face value in Euros. Rating dummy variables indicate initial effective tranche credit rating. Collateral is the type of asset backing the structured bond grouped as commercial and residential mortgages. Issuer fixed effects is a set of dummy variables indicating each issuer. Country dummy variables equal 1 when the asset is originated in the relevant country and 0 otherwise. Time is a factor variable consisting of the issuance periods annually. The omitted categories are tranches rated by 3 agencies, residential mortgage backed notes, and issuance year 2000 . Standard errors in parentheses are clustered at the deal level. ***, **, and * represent significance at the $1 \%, 5 \%$, and $10 \%$ levels, respectively.

Trustee Reputation

Trustee Top5

Trustee Top5 x Boom

Trustee Top5 x 2005

Trustee Top5 x 2006

Trustee Top5 x 2007

Trustee Share

Trustee Share X Boom

Trustee Share X 2005

Trustee Share X 2006

Trustee Share x 2007

Pre-crisis Period

2005

2006

2007

Distance

Retained

Ratings/Tranches

Credit Rating Agencies

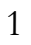

2

\section{(1)}

(2)

(3)

0.1072

-0.0558
$(0.1009)$

0.1190

(0.1093)

$-0.2354 * * *$

(0.0346)

$$
\begin{gathered}
-0.1429^{* * *} \\
(0.0429) \\
-0.2428^{* * *} \\
(0.0399) \\
-0.3702^{* * *} \\
(0.0503)
\end{gathered}
$$

0.0657

(0.2448)

$-2.1493^{* * *}$

(0.4018)
0.0928

(0.2495)

$-1.4949 * *$

(0.5976)

$-2.3755^{* * *}$

(0.4939)

$-2.3475^{* * *}$

(0.4867)

$-0.6331 * * *$

(0.0661)

$-0.6002 * * *$

(0.0610)

$-0.5862^{* * *}$

(0.0697)

$0.1102 * *$

(0.0498)

$-0.0045$

$(0.0238)$

$0.1010^{*}$

(0.0567)

$0.1405^{* * *}$

(0.0454)

$0.0716^{* * *}$

(0.0215) 
Table 4 continued

\begin{tabular}{|c|c|c|c|c|c|c|}
\hline Subordination & $\begin{array}{c}0.2239 * * * \\
(0.0865)\end{array}$ & $\begin{array}{c}0.2362 * * * \\
(0.0854)\end{array}$ & $\begin{array}{c}0.2285^{* * *} \\
(0.0843)\end{array}$ & $\begin{array}{c}0.2361 * * * \\
(0.0857)\end{array}$ & $\begin{array}{c}0.2350^{* * *} \\
(0.0850)\end{array}$ & $\begin{array}{c}0.2319 * * * \\
(0.0847)\end{array}$ \\
\hline Weighted Average Life & $\begin{array}{c}0.3413^{* * * *} \\
(0.0157)\end{array}$ & $\begin{array}{c}0.3426 * * * \\
(0.0157)\end{array}$ & $\begin{array}{c}0.3439 * * * \\
(0.0155)\end{array}$ & $\begin{array}{c}0.3419 * * * \\
(0.0158)\end{array}$ & $\begin{array}{c}0.3426^{* * * *} \\
(0.0159)\end{array}$ & $\begin{array}{c}0.3429 * * * \\
(0.0158)\end{array}$ \\
\hline Size & $\begin{array}{c}0.0008 \\
(0.0060)\end{array}$ & $\begin{array}{l}-0.0004 \\
(0.0061)\end{array}$ & $\begin{array}{c}0.0001 \\
(0.0060)\end{array}$ & $\begin{array}{c}0.0011 \\
(0.0060)\end{array}$ & $\begin{array}{c}0.0002 \\
(0.0061)\end{array}$ & $\begin{array}{c}0.0003 \\
(0.0061)\end{array}$ \\
\hline Step-Up tranche & $\begin{array}{c}-0.1044^{* * *} \\
(0.0344)\end{array}$ & $\begin{array}{c}-0.0952 * * * \\
(0.0328)\end{array}$ & $\begin{array}{c}-0.0976^{* * *} \\
(0.0322)\end{array}$ & $\begin{array}{c}-0.1075^{* * *} \\
(0.0352)\end{array}$ & $\begin{array}{c}-0.1017 * * * \\
(0.0348)\end{array}$ & $\begin{array}{c}-0.1018^{* * *} \\
(0.0348)\end{array}$ \\
\hline \multicolumn{7}{|l|}{ Collateral } \\
\hline Residential Mortgages & $\begin{array}{c}-0.1410^{* * *} \\
(0.0503)\end{array}$ & $\begin{array}{c}-0.1457 * * * \\
(0.0473)\end{array}$ & $\begin{array}{c}-0.1473^{* * *} \\
(0.0467)\end{array}$ & $\begin{array}{c}-0.1367 * * * \\
(0.0501)\end{array}$ & $\begin{array}{c}-0.1295^{* * *} \\
(0.0494)\end{array}$ & $\begin{array}{c}-0.1304 * * * \\
(0.0497)\end{array}$ \\
\hline \multicolumn{7}{|l|}{ Controlled for } \\
\hline Tranche credit rating & Yes & Yes & Yes & Yes & Yes & Yes \\
\hline Trustee fixed effects & Yes & Yes & Yes & Yes & Yes & Yes \\
\hline Issuer fixed effects & Yes & Yes & Yes & Yes & Yes & Yes \\
\hline Country fixed effects & Yes & Yes & Yes & Yes & Yes & Yes \\
\hline Time fixed effects & Yes & Yes & Yes & Yes & Yes & Yes \\
\hline $\mathrm{N}$ & 4,201 & 4,201 & 4,201 & 4,159 & 4,159 & 4,159 \\
\hline Adjusted R ${ }^{2}$ & 0.930 & 0.931 & 0.932 & 0.931 & 0.931 & 0.930 \\
\hline
\end{tabular}




\section{Table 5}

The impact of trustee reputation on initial yield spreads of prime and non-prime MBSs tranches This table reports OLS regressions of the log of initial yield spread (logspread) of European prime and non-prime MBS tranches on trustee reputation, deal, collateral
and tranche-level characteristics. The sample includes all rated floating tranches issued between 1999 and June 2007 . Trustee Share is the number of deals a trustee has
been assigned to as a fraction of the number of all deals issued in the previous year. Trustee Top 5 is a dummy variable that takes the value of 1 if the trustee is one of
the top five trustees in terms of total market volume during this period, and 0 otherwise. Boom equals to 1 if a deal is issued in the years from 2005 to 2007 and 0
otherwise. Ratings/Tranches is the ratio of number of distinct rating classes within a deal divided by number of tranches per deal. Retained is a dummy variable equals
1 if a tranche in the relevant deal is retained. Distance is a dummy variable equals 1 if an issuer's nationality of operations differs from the home country of the parent
institution. Credit Rating Agencies is the number of initial ratings reported for a tranche. Subordination is the value of tranches with an identical or a better rating as a
fraction of the total deal value. Step-up tranche is a dummy variable equal to 1 if the spread quoted at issuance is adjusted upwards on a specified future date and 0
otherwise. Weighted Average Life is the natural logarithm of the mean number of years the principal value of a tranche remains unpaid. Size is the natural logarithm of
tranche face value in Euros. Rating dummy variables indicate initial effective tranche credit rating. Collateral is the type of asset backing the structured bond grouped
as commercial and residential mortgages. Issuer fixed effects is a set of dummy variables indicating each issuer. Country dummy variables equal 1 when the asset is
originated in the relevant country and 0 otherwise. Time is a factor variable consisting of the issuance periods annually. The omitted categories are tranches rated by 3
agencies, residential mortgage backed notes, and issuance year 2000 . Standard errors in parentheses are clustered at the deal level. $* * *, * *$, and $*$ represent significance
at the $1 \%, 5 \%$ and $10 \%$ levels, respectively.

Trustee Reputation

Trustee Top5

Trustee Top5 x Boom

Prime tranches Non-prime tranches

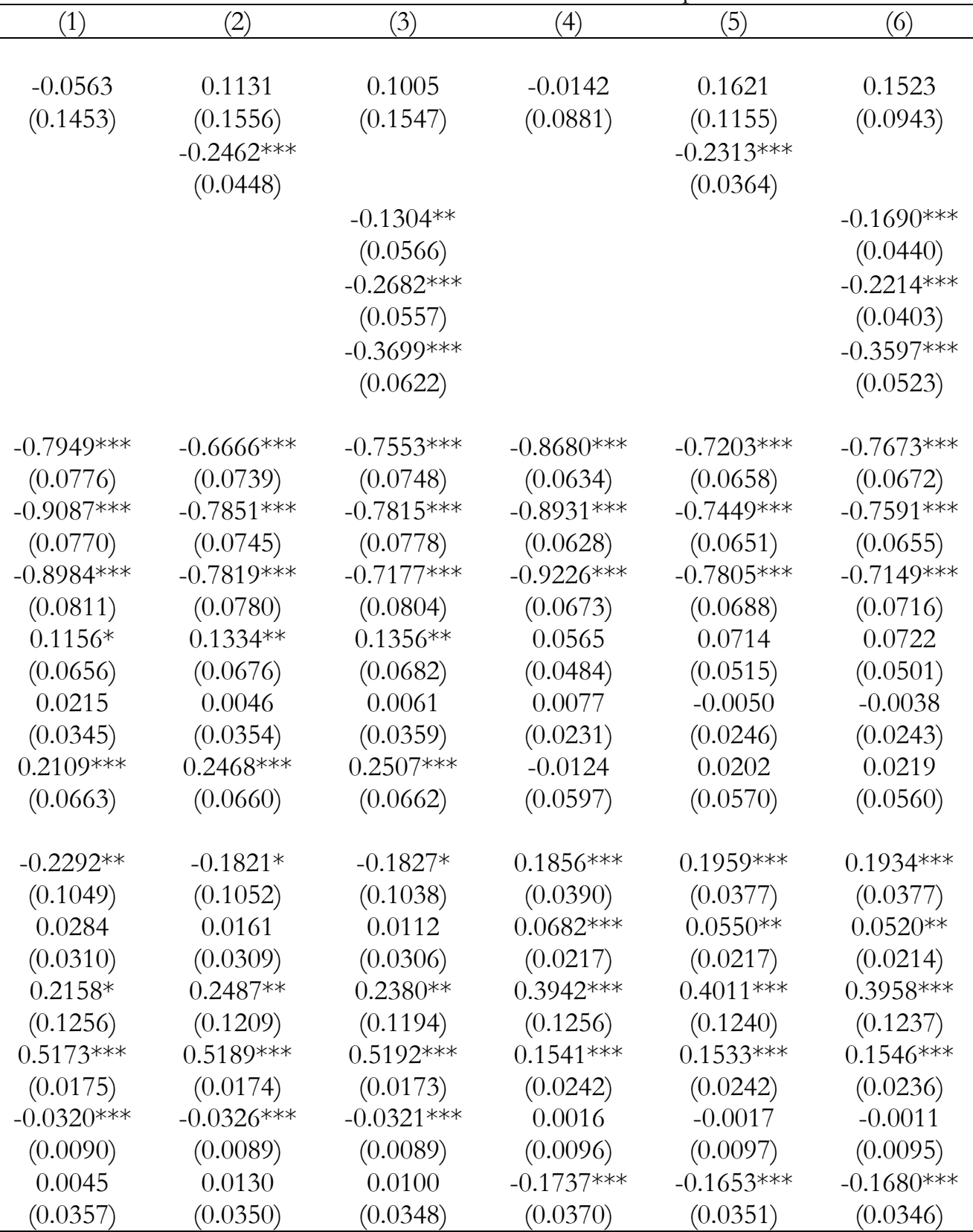


Table 5 continued

\begin{tabular}{lcccccc} 
Collateral & & & \\
Residential Mortgages & $-0.1570^{* *}$ & $-0.1542^{* *}$ & $-0.1584^{* * *}$ & $-0.1113^{* *}$ & $-0.1213^{* *}$ & $-0.1219^{* *}$ \\
& $(0.0647)$ & $(0.0615)$ & $(0.0607)$ & $(0.0516)$ & $(0.0483)$ & $(0.0474)$ \\
Controlled for & & & & & & \\
$\quad$ Tranche credit rating & Yes & Yes & Yes & Yes & Yes & Yes \\
Trustee fixed effects & Yes & Yes & Yes & Yes & Yes & Yes \\
Issuer fixed effects & Yes & Yes & Yes & Yes & Yes & Yes \\
$\quad$ Country fixed effects & Yes & Yes & Yes & Yes & Yes & Yes \\
$\quad$ Time fixed effects & Yes & Yes & Yes & Yes & Yes & Yes \\
$\mathrm{N} \quad$ & 1,568 & 1,568 & 1,568 & 2,633 & 2,633 & 2,633 \\
Adjusted R $\mathrm{R}^{2}$ & 0.826 & 0.831 & 0.833 & 0.929 & 0.931 & 0.932 \\
\hline
\end{tabular}




\section{Table 6}

The impact of trustee reputation on initial yield spreads of prime and non-prime MBSs tranches

This table reports OLS regressions of the log of initial yield spread (logspread) of European prime and non-prime MBS tranches on trustee reputation, deal, collateral and tranche-level characteristics. The sample includes all rated floating tranches issued between 1999 and June 2007. Trustee Share is the number of deals a trustee has been assigned to as a fraction of the number of all deals issued in the previous year. Trustee Top 5 is a dummy variable that takes the value of 1 if the trustee is one of the top five trustees in terms of total market volume during this period, and 0 otherwise. Boom equals to 1 if a deal is issued in the years from 2005 to 2007 and 0 otherwise. Ratings/Tranches is the ratio of number of distinct rating classes within a deal divided by number of tranches per deal. Retained is a dummy variable equals 1 if a tranche in the relevant deal is retained. Distance is a dummy variable equals 1 if an issuer's nationality of operations differs from the home country of the parent institution. Credit Rating Agencies is the number of initial ratings reported for a tranche. Subordination is the value of tranches with an identical or a better rating as a fraction of the total deal value. Step-up tranche is a dummy variable equal to 1 if the spread quoted at issuance is adjusted upwards on a specified future date and 0 otherwise. Weighted Average Life is the natural logarithm of the mean number of years the principal value of a tranche remains unpaid. Size is the natural logarithm of tranche face value in Euros. Rating dummy variables indicate initial effective tranche credit rating. Collateral is the type of asset backing the structured bond grouped as commercial and residential mortgages. Issuer fixed effects is a set of dummy variables indicating each issuer. Country dummy variables equal 1 when the asset is originated in the relevant country and 0 otherwise. Time is a factor variable consisting of the issuance periods annually. The omitted categories are tranches rated by 3 agencies, residential mortgage backed notes, and issuance year 2000 . Standard errors in parentheses are clustered at the deal level. $* * *, * *$, and $*$ represent significance at the $1 \%, 5 \%$, and $10 \%$ levels, respectively.

Trustee Reputation

Trustee Share

Trustee Share X Boom

\begin{tabular}{ccc}
\multicolumn{3}{c}{ Prime tranches } \\
\hline$(1)$ & $(2)$ & $(3)$ \\
$-0.5255^{* *}$ & 0.1245 & 0.1649 \\
$(0.2529)$ & $(0.2593)$ & $(0.2661)$ \\
& $-2.6209 * * *$ & \\
& $(0.5497)$ & \\
& & -1.4896 \\
& & $(1.0140)$ \\
& & $-2.8382^{* * *}$ \\
& & $(0.7485)$ \\
& & $-2.9230 * * *$ \\
& & $(0.5775)$
\end{tabular}

Pre-crisis Period

2005

$-0.7795^{*}$
$(0.0544)$

$-0.5691 * * *$

$-0.8887 * * *$

(0.0661)

2006

$(0.0551)$

2007

$-0.8692 * * *$

$-0.6702^{* * *}$

$-0.6702 * * *$

$-0.7478 * * *$

$(0.0922)$

(0.0703)

(0.0611)

Distance

0.1369*

(0.0711)

$-0.6246^{* * *}$

$-0.6549 * * *$

$(0.0502)$

(0.0835)

$-0.5976 * * *$

$-0.7680 * * *$

(0.0495)

(0.0824)

(0.0818)

$-0.7876^{* * *}$ Non-prime tranches

0.1551 **

0.1571 **

$(0.0550)$

(0.0734)

(0.0743)

0.0628

(0.0494)

0.0050

(5)

(6)

Retained

0.0181

0.0094

0.0103

$(0.0347)$

Ratings/Tranches

$0.2070 * * *$

(0.0353)

(0.0677)

$0.2490 * * *$

(0.0358)

(0.0232)

$-0.0085$

(0.0610)

$-0.6071 * * *$

(0.0589)

$-0.6185^{* * *}$

(0.0598)

$-0.6212 * * *$

(0.0664)

0.0728

(0.0518)

0.0008

0.1380

(0.3161)

(0.3200)

(0.4181)

$-1.5798^{* * *}$

(0.5519)

$-2.0358 * * *$

$(0.4884)$

$-2.0632^{* * *}$

(0.5339)

Credit Rating Agencies

1

$-0.2372 * *$

$-0.2007^{*}$

$-0.2022 *$

$0.1886^{* * * *}$

$(0.0237)$

$-0.6386 * * *$

(0.1074)

(0.1077)

(0.1081)

0.0335

0.0179

0.0131

$(0.0395)$

(0.0312)

(0.0318)

(0.0317)

$0.2283^{*}$

$0.2399 * *$

$0.2315^{*}$

$0.0678^{* * *}$

0.0195

(0.0655)

$-0.6107 * * *$

$(0.0625)$

$-0.6096 * * *$

$(0.0724)$

0.0742

(0.0514)

0.0012

$(0.0238)$

0.0187

(0.0600)

(0.0597)

Subordination

$(0.1272)$

Weighted Average Life

$0.5181^{* * *}$

(0.1218)

(0.1212)

(0.0177)

Size

$-0.0311 * *$

$0.5193^{* * *}$

$0.5194 * * *$

(0.0219)

$0.3988 * * *$

$0.1956 * * *$

$0.1963 * * *$

(0.0387)

$0.0634 * * *$

$(0.0387)$

$0.0621 * * *$

$(0.0223)$

(0.0223)

(0.1256)

$0.4009 * * *$

$0.3998 * * *$

$0.1544 * * *$

(0.1235)

(0.0176)

$(0.0090)$

$-0.0320 * * *$

(0.0176)

(0.0242)

$0.1533 * * *$

(0.1238)

-0.0321 ***

0.0025

(0.0242)

0.1536 ***

$(0.0090)$

(0.0097)

0.0029

$(0.0090)$

0.0085

$-0.1780 * * *$

0.0004

(0.0242)

(0.0097)

0.0004

(0.0365)

(0.0364)

(0.0364)

(0.0379)

(0.0370)

(0.0096)

-0.1736 ***

(0.0371) 


\begin{tabular}{lcccccc}
$\begin{array}{l}\text { Collateral } \\
\text { Residential Mortgages }\end{array}$ & $-0.1491 * *$ & $-0.1394 * *$ & $-0.1412^{* *}$ & $-0.1088^{* *}$ & $-0.1039 * *$ & $-0.1044^{* *}$ \\
& $(0.0646)$ & $(0.0633)$ & $(0.0634)$ & $(0.0515)$ & $(0.0505)$ & $(0.0507)$ \\
$\begin{array}{l}\text { Controlled for } \\
\text { Tranche credit rating }\end{array}$ & Yes & Yes & Yes & Yes & Yes & Yes \\
Trustee fixed effects & Yes & Yes & Yes & Yes & Yes & Yes \\
Issuer fixed effects & Yes & Yes & Yes & Yes & Yes & Yes \\
$\quad$ Country fixed effects & Yes & Yes & Yes & Yes & Yes & Yes \\
$\quad$ Time fixed effects & Yes & Yes & Yes & Yes & Yes & Yes \\
$\mathrm{N} \quad$ & 1,568 & 1,568 & 1,568 & 2,633 & 2,633 & 2,633 \\
Adjusted R $\mathrm{R}^{2}$ & 0.826 & 0.831 & 0.833 & 0.929 & 0.931 & 0.932 \\
\hline
\end{tabular}




\section{References}

ABA (2010), The Trustee's Role in Asset-Backed Securities. American Bankers Association.

Adelino, M. (2009), Do investors rely only on ratings? The case of mortgage-backed securities. Job Market Paper. MIT Sloan School of Management and Federal Reserve Bank of Boston.

Allen, F. \& Santomero, A. M. (1997), "The theory of financial intermediation." Journal of Banking \& Finance, Vol. 21, No.11: pp. 1461-1485.

Allon, S. (2009), "The Servicer's Role in Managing Complex Structured Transactions." Journal of Structured Finance, Vol. 15, No.2: pp. 66-69,6-7.

Altunbas, Y., Gambacorta, L. \& Marques-Ibanez, D. (2009), "Securitisation and the bank lending channel." European Economic Review, Vol. 53, No.8: pp. 996-1009.

Amihud, Y., Garbade, K. \& Kahan, M. (2000), "An Institutional Innovation to Reduce the Agency Costs of Public Corporate Bonds." Journal of Applied Corporate Finance, Vol. 13, No.1: pp. 114-121.

Andres, C., Betzer, A. \& Limbach, P. (2012), Delegated Monitoring: the Effectiveness and Pricing of Bond Indenture Trustees. Available at SSRN 2024556.

Ashcraft, A. B. \& Schuermann, T. (2008), "Understanding the securitization of subprime mortgage credit." Federal Reserve Bank of New York Staff Reports, No.318: pp. 1-82.

Bavoso, V. (2015), Filling the Accountability Gap in Structured Finance Transactions: The Case for a Broader Fiduciary Obligation. Available at SSRN 2529413.

Bazzana, F. (2012), "Bondholder's Trustee." in Backhaus, J. (Ed.) Encyclopedia of Law and Economics. New York, Springer: pp. 1-4.

Berger, A. N., Klapper, L. F., Martinez Peria, M. S. \& Zaidi, R. (2008), "Bank ownership type and banking relationships." Journal of Financial Intermediation, Vol. 17, No.1: pp. 37-62.

Berlin, M. \& Loeys, J. A. N. (1988), "Bond Covenants and Delegated Monitoring." The Journal of Finance, Vol. 43, No.2: pp. 397-412.

Boot, A. W. A. \& Thakor, A. V. (1993), "Security Design." The Journal of Finance, Vol. 48, No.4: pp. 13491378.

Booth, J. R. \& Smith, R. L. (1986), "Capital raising, underwriting and the certification hypothesis." Journal of Financial Economics, Vol. 15, No.1: pp. 261-281.

Brennan, M. J., Hein, J. \& Poon, S.-H. (2009), "Tranching and Rating." European Financial Management, Vol. 15, No.5: pp. 891-922.

Buckley, K. J. (2010), "Securitization Trustee Issues." The Journal of Structured Finance, Vol. 16, No.2: pp. 47-52.

Campbell, J. Y. \& Taksler, G. B. (2003), "Equity Volatility and Corporate Bond Yields." The Journal of Finance, Vol. 58, No.6: pp. 2321-2350.

Carbo-Valverde, S., Rodriguez-Fernandez, F. \& Saunders, A. (2015), Underwriting as Certification of Bank Bonds. Available at SSRN 2665917. 
Cetorelli, N. \& Peristiani, S. (2012), "The role of banks in asset securitization." Federal Reserve Bank of New York Economic Policy Review, Vol. 18, No.2: pp. 47-64.

Chemmanur, T. J. \& Fulghieri, P. (1994), "Investment bank reputation, information production, and financial intermediation." The Journal of Finance, No.57-79.

Choudhry, M. (2013), "The Mechanics of Securitization: A Practical Guide to Structuring and Closing Assetbacked Security Transactions, "New Jersey, John Wiley \& Sons.

Coleman, D. \& Libunao, J. (2013), Roles and Responsibilities of the Issuer and Trustee. California Debt and Investment Advisory Commission Seminars. Oakland, California.

Coles, A. \& Hardt, J. (2000), "Mortgage Markets: Why US and EU Markets Are So Different." Housing Studies, Vol. 15, No.5: pp. 775-783.

Colloff, M. A. (2005), "The Role of the Trustee in Mitigating Fraud in Structured Financings." Journal of Structured Finance, Vol. 10, No.4: pp. 73-80.

Coval, J., Jurek, J. \& Stafford, E. (2009), "The Economics of Structured Finance." Journal of Economic Perspectives, Vol. 23, No.1: pp. 3-25.

Cuchra, M. F. (2005), "Explaining Launch Spreads on Structured Bonds." Discussion Paper No. 230, No.

Cuchra, M. F. \& Jenkinson, T. (2005), Security Design in the Real World: Why are Securitization Issues Tranched? Working Paper. University of Oxford.

Detragiache, E., Tressel, T. \& Gupta, P. (2008), "Foreign Banks in Poor Countries: Theory and Evidence." The Journal of Finance, Vol. 63, No.5: pp. 2123-2160.

Diamond, D. W. (1984), "Financial Intermediation and Delegated Monitoring." The Review of Economic Studies, Vol. 51, No.3: pp. 393-414.

Diamond, D. W. (1996), "Financial intermediation as delegated monitoring: A simple example." Federal Reserve Bank of Richmond Economic Quarterly, Vol. 82, No.3: pp. 51.

Dolmetsch, C. (2014), BlackRock, Pimco Sue Banks for Mortgage-Bond Trustee Role. Bloomberg News. Bloomberg.com.

ECB (2013), "Reference interest rates: role, challenges and outlook." ECB Monthly Bulletin, Vol. 2013, No.10: pp. 69-84.

ECB (2014), "Euro Area Risk-Free Interest Rates: Measurement Issues, Recent Developments and Relevance to Monetary Policy." ECB Monthly Bulletin, Vol. 2014, No.07: pp. 63-77.

ESMA (2015), Competition and choice in the credit rating industry. Paris, European Securities and Markets Authority.

Fabozzi, F. J. \& Vink, D. (2012a), "Determinants of Primary Market Spreads on U.K. Residential MortgageBacked Securities and the Implications for Investor Reliance on Credit Ratings." Journal of Fixed Income, Vol. 21, No.3: pp. 7-14.

Fabozzi, F. J. \& Vink, D. (2012b), "Looking Beyond Credit Ratings: Factors Investors Consider In Pricing European Asset-Backed Securities." European Financial Management, Vol. 18, No.4: pp. 515-542. 
Fabozzi, F. J. \& Vink, D. (2015), "The information content of three credit ratings: the case of European residential mortgage-backed securities." European Journal of Finance, Vol. 21, No.3: pp. 172-194.

Fang, L. H. (2005), "Investment bank reputation and the price and quality of underwriting services." The Journal of Finance, Vol. 60, No.6: pp. 2729-2761.

Franke, G., Herrmann, M. \& Weber, T. (2012), "Loss Allocation in Securitization Transactions." Journal of Financial and Quantitative Analysis, Vol. 47, No.5: pp. 1125-1153.

Frankel, D. M. \& Jin, Y. (2015), "Securitization and Lending Competition." Review of Economic Studies, Vol. 82, No.4: pp. 1383-1408.

Furfine, C. H. (2014), "Complexity and Loan Performance: Evidence from the Securitization of Commercial Mortgages." The Review of Corporate Finance Studies, Vol. 2, No.2: pp. 154-187.

Ghent, A. C., Torous, W. N. \& Valkanov, R. I. (2017), Complexity in Structured Finance. Available at SSRN 2325835 .

Gorton, G. \& Metrick, A. (2012a), "Securitization." National Bureau of Economic Research Working Paper Series, No.18611: pp. 1-96.

Gorton, G. \& Metrick, A. (2012b), "Securitized banking and the run on repo." Journal of Financial Economics, Vol. 104, No.3: pp. 425-451.

Grbac, Z. \& Runggaldier, W. (2015), "No arbitrage conditions in HJM multiple curve term structure models," 7th General AMaMeF and Swissquote Conference, at Lausanne, Switzerland.

Güntay, L. \& Hackbarth, D. (2010), "Corporate bond credit spreads and forecast dispersion." Journal of Banking \& Finance, Vol. 34, No.10: pp. 2328-2345.

Guo, G. \& Wu, H.-M. (2014), "A study on risk retention regulation in asset securitization process." Journal of Banking \& Finance, Vol. 45, No.0: pp. 61-71.

Haubrich, J. G. (1989), "Financial intermediation: Delegated monitoring and long-term relationships." Journal of Banking \& Finance, Vol. 13, No.1: pp. 9-20.

He, J., Qian, J. \& Strahan, P. E. (2016), "Does the Market Understand Rating Shopping? Predicting MBS Losses with Initial Yields." Review of Financial Studies, Vol. 29, No.2: pp. 457-485.

He, J. J., Qian, J. Q. \& Strahan, P. E. (2012), "Are All Ratings Created Equal? The Impact of Issuer Size on the Pricing of Mortgage-Backed Securities." The Journal of Finance, Vol. 67, No.6: pp. 2097-2137.

Jiang, W., Nelson, A. A. \& Vytlacil, E. (2013), "Liar's Loan? Effects of Origination Channel and Information Falsification on Mortgage Delinquency." Review of Economics and Statistics, Vol. 96, No.1: pp. 1-18.

Kara, A., Marques-Ibanez, D. \& Ongena, S. (2016), "Securitization and lending standards: Evidence from the European wholesale loan market." Journal of Financial Stability, Vol. 26, No.107-127.

Keys, B. J., Mukherjee, T., Seru, A. \& Vig, V. (2009), "Financial regulation and securitization: Evidence from subprime loans." Journal of Monetary Economics, Vol. 56, No.5: pp. 700-720.

Keys, B. J., Seru, A. \& Vig, V. (2012), "Lender Screening and the Role of Securitization: Evidence from Prime and Subprime Mortgage Markets." Review of Financial Studies, Vol. 25, No.7: pp. 2071-2108. 
Kiff, J. \& Kisser, M. (2014), "A shot at regulating securitization." Journal of Financial Stability, Vol. 10, No.3249.

Kothari, V. (2006), "Securitization: The Financial Instrument of the Future," Singapore, John Wiley \& Sons.

Kuncl, M. (2015), Securitization under Asymmetric Information over the Business Cycle. Working Paper No. 2015-9. Bank of Canada.

Levitin, A. J. (2010), Robo-Signing, Chain of Title, Loss Mitigation, and Other Issues in Mortgage Servicing: Hearing Before the Subcomm. on Hous. and Cmty. Opportunity of the H. Fin. Serv. Comm., 111th Cong., Nov. 18, 2010 (Statement of Associate Professor Adam J. Levitin, Geo. UL Center).

Loutskina, E. \& Strahan, P. E. (2011), "Informed and Uninformed Investment in Housing: The Downside of Diversification." Review of Financial Studies, Vol. 24, No.5: pp. 1447-1480.

Macaulay, S. J. (2004), "The Role of the Securitisation Trustee." Global Securitisation and Structured Finance 2004. London, Deutsche Bank \& Global White Page

Mahlmann, T. (2012), "Did investors outsource their risk analysis to rating agencies? Evidence from ABSCDOs." Journal of Banking \& Finance, Vol. 36, No.5: pp. 1478-1491.

McQueen, S., Gorel, G. A. \& van Heerden, C. (2013), An Investor's Guide to The Pooling and Servicing Agreement. Dechert LLP and Wells Fargo Securities, LLC.

Mian, A. (2006), "Distance Constraints: The Limits of Foreign Lending in Poor Economies." The Journal of Finance, Vol. 61, No.3: pp. 1465-1505.

Morton, R. (2005), "The changing face of the structured finance markets in Europe: a trustee's perspective." Global Securitisation and Structured Finance 2005. London, Deutsche Bank \& Global White Page

Petersen, M. A. (2009), "Estimating Standard Errors in Finance Panel Data Sets: Comparing Approaches." Review of Financial Studies, Vol. 22, No.1: pp. 435-480.

Richardson, M. \& White, L. (2009), "The Rating Agencies: Is Regulation the Answer?" Financial Markets, Institutions \& Instruments, Vol. 18, No.2: pp. 146-148.

Riddiough, T. J. (1997), "Optimal design and governance of asset-backed securities." Journal of Financial Intermediation, Vol. 6, No.2: pp. 121-152.

Sangiorgi, F., Sokobin, J. \& Spatt, C. (2009), Credit-rating shopping, selection and the equilibrium structure of ratings. Working Paper. Stockholm School of Economics and Carnegie Mellon University.

Schaber, A. (2008), Combination notes: market segmentation and equity transfer. Discussion Paper 2008-6. Munich School of Management.

Schwarcs, S. L. \& Sergi, G. M. (2008), "Bond Defaults and the Dilemma of the Indenture Trustee." Alabama Law Review, Vol. 59, No.1037-1074.

SEC (2014), Asset-Backed Securities Disclosure and Registration. IN Commission, S. a. E. (Ed.) 2014-21375.

Segoviano, M. A., Jones, B., Lindner, P. \& Blankenheim, J. (2015), Securitization: The Road Ahead. IMF Staff Discussion Note SDN15/01. IMF.

SIFMA (2017), Europe Structured Finance Issuance and Outstanding. Structured Finance. 
Skreta, V. \& Veldkamp, L. (2009), "Ratings shopping and asset complexity: A theory of ratings inflation." Journal of Monetary Economics, Vol. 56, No.5: pp. 678-695.

Smith, C. W. \& Warner, J. B. (1979), "On financial contracting." Journal of Financial Economics, Vol. 7, No.2: pp. 117-161.

Spiotto, J. E. (2012), "The Role of the Municipal Bond Trustee." The Handbook of Municipal Bonds. John Wiley \& Sons, Inc.: pp. 127-144.

Stein, J. C. (2002), "Information Production and Capital Allocation: Decentralized versus Hierarchical Firms." The Journal of Finance, Vol. 57, No.5: pp. 1891-1921.

Stempel, J. (2016), Deutsche Bank must face U.S. lawsuit over $\$ 3.1$ bln mortgage loss - judge. Reuters. Reuters.

Stone, C. A. \& Zissu, A. (2000), "Securitization: The Transformation of Illiquid Financial Assets into Liquid Capital Market Securities Examples from the European Market." Financial Markets, Institutions \& Instruments, Vol. 9, No.3-4: pp. 133-278.

Titman, S. \& Trueman, B. (1986), "Information quality and the valuation of new issues." Journal of Accounting and Economics, Vol. 8, No.2: pp. 159-172.

Whetten, M. \& Adelson, M. (2004), "Tranching Credit Risk." Nomura Fixed Income Research, No.10: pp. 118.

Wilmington Trust. (2017), 'Role of the Trustee in Asset Securitization' Available at: <http://s13754.p146.sites.pressdns.com/corporate-institutional/role-of-the-trustee-in-assetsecuritization>. (accessed 03/02/2017).

Yoon, A. (2014), BlackRock, Pimco Sue Deutsche Bank, U.S. Bank Over Trustee Roles. The Wall Street Journal. 